\title{
PENGEMBANGAN LKS BERDASARKAN IDENTIFIKASI TUMBUHAN PAKU EPIFIT PADA BATANG KELAPA SAWIT
}

\author{
Yemi Ulviani $^{1^{*}}$, Kasrina ${ }^{1}$, Irdam Idrus ${ }^{1}$ \\ ${ }^{1}$ Program Studi Pendidikan Biologi, Fakultas Keguruan dan Ilmu Pendidikan, Universitas Bengkulu \\ Email: yemiulviani03@gmail.com
}

\begin{abstract}
Abstrak
Penelitian ini bertujuan untuk mendeskripsikan desain Lembar Kerja Siswa berdasarkan identifikasi tumbuhan paku (Pteridophyta) epifit. Penelitian ini terdiri dari 6 tahapan yaitu 1) Tahap identifikasi masalah dan potensi 2) Pengumpulan informasi 3) Desain produk 4) Validasi desain 5) Revisi 6) Uji keterbacaan LKS. Subjek penelitian ini adalah siswa/siswi kelas X MIPA 1 SMAN 3 kota Bengkulu. Teknik pengumpulan data pada penelitian adalah angket dan observasi. Hasil penelitian teridentifikasi 8 Jenis tumbuhan paku (Pteridophyta) epifit pada batang kelapa sawit yang digunakan sebagai bahan pembuatan LKS. Uji kelayakan LKS pada aspek kelayakan isi diperoleh skor 18 dengan persentase kategori sangat baik 90\%, aspek penyajian diperoleh skor 6,7 persentase kategori sangat baik $83 \%$, aspek kebahasaan diperoleh skor 6,3 persentase kategori baik $78 \%$ dan aspek kegrafisan diperoleh skor 14,3 dengan persentase kategori sangat baik $89 \%$ serta secara keseluruhan diperoleh skor 45,3 dengan pesentase kategori sangat baik 87\%. Hasil uji keterbacaan siswa secara keseluruhan menunjukkan skor 35,7 dengan persentase kategori sangat baik. Berdasarkan hasil validasi dan uji keterbacaan, dapat disimpulkan bahwa LKS yang dikembangkan layak dan memiliki kualitas baik.
\end{abstract}

Kata kunci: Pengembangan LKS, Paku epifit

\begin{abstract}
The study aimed to describe the design of LKS based on identification of epiphyte fern. This study consists of 6 stages: 1) Problem identification stage and potential 2) Information gathering 3) Product design 4) Design validation 5) Revision 6) Test of LKS legibility. The subjects of this study were students of grade X MIPA 1 SMAN 3 Bengkulu city. Data collection techniques in the study were questionnaires and observations. The results of the research identified 8 species of epiphyte ferns (Pteridopyta) on the steam palm oil rod that used as a material for making LKS. LKS feasibility test on content feasibility aspect got score 18 with very good $90 \%$ category percentage, presentation aspect got score 6.7 percentage category very good $83 \%$, linguistic aspect got score 6.3 percentage category good $78 \%$ and aspect of scores obtained score 14,3 with excellent category percentage $89 \%$ and overall got score 45,3 with very good category percentage $87 \%$. The results of the overall student legibility test showed a score of 35.7 with a very good category percentage. Based on the validation and legibility test results, it can be concluded that the LKS is developed feasible and has good quality.
\end{abstract}

Keyword : The development of student worksheet,, Epiphyte ferns

\section{PENDAHULUAN}

Implementasi kurikulum 2013 menuntut adanya perangkat pembelajaran yang kreatif, inovatif, variatif, menarik dan kontekstual yang di rancang sendiri oleh guru sesuai dengan karakteristik materi ajar yang akan disajikan dan sesuai dengan tingkat kebutuhan peserta didik di kelas sehingga mem- permudah peserta didik dalam memahami materi yang sedang dipelajari (Permendikbud, 2016). Serta guru juga dituntut untuk mengembangkan dan meningkatkan kualitas pembelajaran. Salah satunya adalah memberikan pengalaman belajar secara langsung (real experience) yang menuntut peserta didik untuk melakukan pembelajaran secara otentik. Pembelajaran otentik dapat terjadi ketika guru 
memberikan kesempatan belajar yang bermakna melalui aneka bahan ajar dari sumber belajar lingkungan.

Kenyataan yang ada berdasarkan analisis peneliti terhadap bahan ajar materi Biologi di salah satu SMA Negeri yang telah menerapkan kurikulum 2013 di Kota Bengkulu. Ditemukan bahan ajar berupa LKS (Lembar Kerja Siswa) pada materi plantae submateri tumbuhan paku belum sesuai dengan karakteristik materi ajar yang disajikan dan belum sesuai de-ngan kebutuhan siswa. Hal ini dapat dilihat dari aspek kelengkapan komponen, didalam LKS yang hanya terdapat kom-ponen judul, tujuan, dan pertanyaan-per-tanyaan pengamatan.

Kegiatan pengamatan di dalam LKS hanya berdasarkan gambar serta siswa belum dituntun untuk melakukan pengamatan menggunakan prosedur pengamatan yang seharusnya ada di dalam LKS. Berdasarkan hasil analisis kurikulum yang telah dilakukan kompetensi dasar yang harus dimiliki siswa pada materi plantae ini adalah siswa mampu mengelompokkan tumbuhan ke dalam divisio berdasarkan ciri-ciri umum, serta mengaitkan peranannya dalam kehidupan. Untuk mencapai kompetensi tersebut bahan ajar yang dibutuhkan siswa adalah bahan ajar yang dapat menuntun siswa melakukan pengamatan secara langsung menggunakan langkahlangkah ilmiah agar dapat menemukan konsep tentang pengelompok-kan tumbuhan tersebut. Setelah itu untuk menyediakan bahan ajar yang bervariatif hendaknya materi yang disajikan merupakan informasi baru yang dapat menambah wawasan siswa.

Salah satu upaya yang dapat dilakukan untuk meningkatkan kualitas pembelajaran tersebut adalah dengan mengembangkan suatu bahan ajar berdasarkan potensi lingkungan sekiar sekolah. Dari hasil pengamatan awal lingkungan sekitar
SMAN 3 kota Bengkulu selain masih terdapat perkebunan-perkebunan yang berpotensi dijadikan sumber belajar. Salah satunya yaitu perkebunan kelapa sawit di kawasan gedung STQ Kelurahan Suka-rami kota Bengkulu.

Dalam pengamatan awal banyak ditemukan tumbuhan paku yang menempel (epifit) di batang kelapa sawit. Melimpahnya tumbuhan paku epifit ini sangat berpotensi untuk dijadikan informasi baru pembuatan bahan ajar LKS berdasarkan potensi lingkungan sekitar pada materi Plantae submateri tumbuhan paku (Pteridophyta). Untuk itu dilakukan penelitian dengan tujuan untuk mendeskripsikan desain LKS yang digunakan pada materi plantae SMA kelas $X$ berdasarkan identifikasi tumbuhan paku (Pteridopyta) epifit pada batang kelapa sawit di Kelurahan Sukarami kota Bengkulu.

\section{METODE}

Penelitian ini dilakukan pada bulan Maret hingga April 2017 di area perkebunan sawit gedung STQ Kelurahan Sukarami kota Bengkulu serta uji keterbacaan LKS dilakukan pada bulan Mei di SMAN 3 Kota Bengkulu. Alat dan bahan yang digunakan Cutter, Tali Plastik atau Tali raffia, Gunting, Kamera, Penggaris, Pena dan Kertas serta bahan yang digunakan Tanaman Paku, silabus dan RPP SMA, Buku IPA SMA Kelas X.

Teknik pengumpulan data yang digunakan dalam penelitian ini adalah angket dan observasi. Penggunaan angket pada penelitian ini yaitu pada uji kelayakan LKS oleh dosen ahli yang terdiri dari ahli materi dan ahli bahan ajar serta guru Biologi sebagai praktisi dan pada siswa untuk uji keterbacaan terhadap LKS hasil pengembangan. Sedangkan Observasi yang di maksud dalam teknik pengumpulan data ini ialah observasi tumbuhan 
paku epifit sebagai sumber pembuatan bahan ajar.

Penelitian ini dilaksanakan menurut langkah-langkah penelitian Borg dan Gall (1981) dalam Sugiyono (2010) yang dibatasi pada tahap uji coba produk. Adapun tahapan tersebut terdiri dari: a. Identifikasi potensi dan masalah, b. Pengumpulan informasi c. Desain produk, d. Validasi desain, e. Perbaikan desain (revisi) f. Uji keterbacaan.

Data validasi dari ahli materi, ahli bahan ajar dan guru Biologi serta uji keterbacaan oleh siswa dianalisis dengan mentabulasi data yang diperoleh ke dalam skor untuk memudahkan proses selanjutnya. Tabel 1 berikut ini merupakan pedoman penilaian pada lembar penilaian kualitas LKS dan uji keterbacaan siswa.

Tabel 1. Pedoman penilaian pada lembar penilaian kualitas dan uji keterbacaan LKS.

\begin{tabular}{cc}
\hline Alternatif penilaian & Nilai \\
\hline Sangat baik & 4 \\
Baik & 3 \\
Cukup & 2 \\
Kurang & 1 \\
\hline
\end{tabular}

Perhitungan skor rata-rata skor tiap aspek. Setelah ditabulasi skor hasil perhitungan tiap aspek LKS kemudian dihitung dengan menggunakan rumus sebagai berikut.

$$
\begin{aligned}
& X=\frac{\sum X}{n} \text {. } \\
& \text { Keterangan : } \\
& \mathrm{X}=\text { Skor rata-rata } \\
& \Sigma \mathrm{X}=\text { Jumlah skor } \\
& \mathrm{n} \quad=\text { Jumlah penilai } \\
& \text { (Sumber : Widoyoko, 2009) }
\end{aligned}
$$

Perbandingan Rata-rata Skor Tiap Aspek dengan Kriteria yang Ditentukan. Pada tahap ini, rata-rata skor tiap aspek yang telah di dapat pada tahap sebelumnya dinyatakan dalam nilai kualitatif. Cara yang digunakan untuk menyatakan ratarata skor tiap aspek dalam nilai kualitatif adalah dengan membandingkannya deng-

\begin{tabular}{|c|c|c|}
\hline No & Interval rata-rata & Kriteria \\
\hline 1 & $X>X i+1,8 . S b i$ & $\begin{array}{c}\text { Sangat } \\
\text { Baik }\end{array}$ \\
\hline 2 & $\mathrm{Xi}+0,6 \times \mathrm{Sbi}<\mathrm{X} \leq \mathrm{Xi}+1,8 . \times \mathrm{Sbi}$ & Baik \\
\hline 3 & $\mathrm{Xi}-0,6 . x \mathrm{Sbi}<\mathrm{X} \leq \mathrm{Xi}+0,6 . \times \mathrm{Sbi}$ & Cukup Baik \\
\hline 4 & Xi - 1,8.x Sbi <X $\leq X i-0,6 . x$ Sbi & $\begin{array}{c}\text { Kurang } \\
\text { Baik }\end{array}$ \\
\hline
\end{tabular}
an kriteria penilaian kualitas tertentu.
Kriteria yang digunakan dalam penelitian ini disajikan dalam Tabel 2 berikut:

Tabel 2. Kriteria Penilaian Kualitas dan uji keterbacaan LKS

Keterangan:

Xi = Rerata ideal

$=\frac{1}{2}$ (skor maksimum ideal + skor minimum ideal)

Sbi = Simpangan baku ideal $=\frac{1}{6}$ (skor maksimum ideal - skor minimum ideal)

$\mathrm{X}=$ Skor empiris

Dalam penelitian ini, kriteria penilaian dibatasi pada kriteria 4 sehingga skor maksimum ideal adalah 4 dan skor minimum ideal adalah 1 . Kemudian menentukan persentase keidealan tiap aspek dan secara keseluruhan dengan rumus :

Persentase keidealan tiap aspek = $\sum \frac{\text { skor rata-rata }}{\text { skor maksimal tiap aspek }} \times 100 \%$

Persentase keidealan keseluruhan $\sum \frac{\text { skor rata-rata keseluruhan }}{\text { skor maksimal keseluruhan }} \times 100 \%$

\section{HASIL DAN PEMBAHASAN}

Hasil identifikasi dari tumbuhan paku epifit dikembangkan menjadi suatu produk bahan ajar berupa Lembar kerja Siswa (LKS) pada materi plantae submateri tumbuhan paku (Pteridophyta) untuk SMA kelas X. Adapun Hasil identifikasi tumbuhan paku epifit yang teridentifikasi berasal dari 1 kelas yaitu Filiicinae, 1 ordo yaitu Polipodiales, 4 famili yaitu Aspleni- 
aceae, Davaliaceae, Nephrolepida-ceae, dan Polipodiaceae yang tediri dari 8 jenis yaitu Davalia trichomanoides, Davalia denticulata, Drymoglossum piloselloides, Nephrolepis biseratta, Phymatosorus scolopendria, Pyrrosia lanceolata, Asplenium nidus, Goniophlebium percussum.

\section{Hasil Produk Lembar Kerja Siswa}

Lembar Kerja Siswa yang dikembangkan terdiri dari 13 halaman. Adapun aspek yang dikembangkan yaitu meliputi aspek desain, struktur LKS, tujuan pembelajaran, materi, kegiatan siswa, dan pertanyaan diskusi. Tampilan desain cover LKS yang telah dikembangkan dapat dilihat pada gambar 1 . Cover, didesain dengan menampilkan beberapa foto-foto tumbuhan paku epifit pada batang kelapa sawit tujuannya adalah agar tampilan depan LKS dapat mewakili isi LKS yaitu tentang tumbuhan paku epifit. Kemudian pada cover mengandung beberapa komponen seperti submateri tumbuhan paku (Pteridophta), kolom untuk mengisi nama kelompok dan nama anggota kelompok sebagai identitas siswa.

Tabel 3. Validasi LKS Berdasarkan Identifikasi Tumbuhan Paku Epifit

\begin{tabular}{|c|c|c|c|c|c|c|c|}
\hline \multirow[t]{2}{*}{ No } & \multirow[t]{2}{*}{ Aspek } & \multicolumn{3}{|c|}{ Skor } & \multirow{2}{*}{$\begin{array}{c}\text { Rata- } \\
\text { rata }\end{array}$} & \multirow{2}{*}{$\begin{array}{c}\text { Persentase } \\
(\%)\end{array}$} & \multirow[t]{2}{*}{ Kriteria } \\
\hline & & $\begin{array}{c}\text { Ahli } \\
\text { bahan } \\
\text { ajar }\end{array}$ & $\begin{array}{c}\text { Ahli } \\
\text { materi }\end{array}$ & $\begin{array}{c}\text { Guru } \\
\text { Biologi } \\
\text { SMA }\end{array}$ & & & \\
\hline 1 & $\begin{array}{l}\text { Kelayakan } \\
\text { materi/isi }\end{array}$ & 19 & 16 & 19 & 18 & 90 & Sangat baik \\
\hline 2 & $\begin{array}{l}\text { Penyajian } \\
\text { materi/isi }\end{array}$ & 7 & 6 & 7 & 6,7 & 83 & Sangat Baik \\
\hline 3 & Kebahasaan & 6 & 6 & 7 & 6,3 & 78 & Baik \\
\hline \multirow[t]{2}{*}{4} & Grafis & 16 & 12 & 15 & 14,3 & 89 & Sangat Baik \\
\hline & Jumlah & 40 & 47 & 49 & 45,3 & 87 & Sangat Baik \\
\hline
\end{tabular}

\section{Hasil Uji Keterbacaan}

Setelah dilakukan validasi, untuk mengetahui tanggapan siswa terhadap LKS hasil pengembangan dilakukan uji keterbacaan atau uji respon siswa. Uji ini

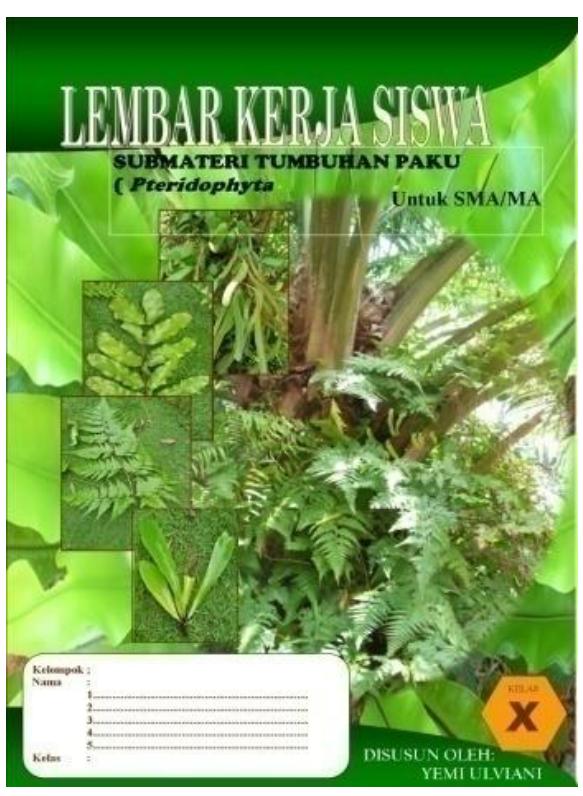

Gambar 1. Desain cover LKS

\section{Hasil validasi LKS}

Setelah didesain, untuk menghasilkan bahan ajar LKS yang layak atau valid untuk digunakan dilakukan validasi oleh dua dosen ahli yaitu ahli bahan ajar dan ahli materi serta oleh seorang guru Biologi SMA. .Adapun Tabel hasil validasi dapat dilihat pada Tabel 4.

dapat dijadikan sebagai tolak ukur kualitas perangkat pembelajaran yang telah dikembangkan dari aspek kepraktisan. Adapun hasil uji keterbacaan dari 33 orang siswa/i kelas X MIPA 1 SMAN 3 kota Bengkulu dapat dilihat pada Tabel 4. 
Tabel 4. Hasil Uji Keterbacaan LKS

\begin{tabular}{ccccc}
\hline No & Aspek & Rata-rata & Persentase (\%) & Kriteria \\
\hline 1 & Materi & 18 & 90 & Sangat Baik \\
2 & $\begin{array}{c}\text { Bahasa, } \\
\text { Gambar dan } \\
\text { Foto }\end{array}$ & 7 & 87 & Sangat Baik \\
& Kegrafisan & 11 & 91 & Sangat Baik \\
\hline & Jumlah & 35,7 & 89 & Sangat Baik
\end{tabular}

\section{PEMBAHASAN}

\section{Produk Lembar Kerja Siswa}

Hasil identifikasi tumbuhan paku epifit pada batang kelapa sawit di kawasan perkebunan sawit gedung STQ Kelurahan Sukarami Kota Bengkulu me-rupakan potensi sumber belajar yang ada dilingkungan siswa yang kemudian dikembangkan menjadi bahan ajar berupa Lembar Kerja Siswa (LKS) pada materi plantae submateri tumbuhan paku (Pte-ridophyta). Pada penelitian ini LKS dikem-bangkan dengan menerapkan pendekatan keterampilan proses. Pembelajaran ber-basis keterampilan proses sains menekan-kan pada kemampuan siswa dalam mene-mukan sendiri (discover) pengetahuan yang didasarkan atas pengalaman belajar, hukum-hukum, prinsipprinsip dan gene-ralisasi, sehingga lebih memberikan kes-empatan bagi berkembangnya ke-terampilan berpikir tingkat tinggi.

Dalam LKS ini keterampilan proses sains yang diimplimentasikan ke dalam LKS terdiri dari keterampilan mengamati, menggolongkan, menganalisis, menyimpulkan dan mengkomunikasikan. Adapun keterampilan mengamati diimplemen-tasikan pada saat kegiatan siswa meng-amati karakter morfologi dari paku epifit. Keterampilan mengamati perlu dilatihkan pada siswa karena kemampuan untuk membuat pengamatan yang baik sangat penting untuk perkembangan keterampil-an proses sains lainnya.

Keterampilan yang kedua yaitu menggolongkan. Keterampilan ini dilatihkan pada kegiatan siswa me-ngelompok-kan tumbuhan paku epifit ber-dasarkan kesamaan karakter morfologi-nya, sedangakan keterampilan meng-analisis yaitu dilatihkan pada kegiatan siswa menjawab pertanyaan-pertanyaan diskusi berdasarkan hasil pengamatan dan terakhir yaitu keterampilam mengko-munikasikan dilatihkan pada saat siswa menyampaikan hasil pengamatan yang telah dilakukan.

Adapun aspek yang dikembangkan pada LKS ini meliputi aspek desain, struktur LKS, tujuan pembelajaran, materi, kegiatan siswa, dan pertanyaan diskusi. Desain LKS dirancang dengan meng-gunakan ukuran A4 (kuarto), kepadatan halaman yang rendah dan penomoran yang jelas antara judul dan sub judul. Prastowo (2011) menyimpulkan bahwa LKS yang memiliki desain sulit dan rumit, akan menyulitkan siswa memahami ma-teri. Desain LKS didominasi oleh warna hijau dan dikombinasikan dengan beberapa foto tumbuhan paku epifit hasil peng-amatan untuk menarik minat siswa dalam belajar.

Tujuan pembelajaran pada LKS disesuaikan dengan tujuan pembelajaran pada RPP yang dikembangkan dari Kompetensi Dasar (KD) yang harus dicapai siswa pada materi plantae. Sedangkan untuk bagian materi pengantar LKS menggunakan data dari hasil penelitian paku epifit pada batang kelapa sawit yang dicontohkan dengan tumbuhan paku epifit yang paling banyak ditemukan yaitu Davalia trichomanoides.

Prosedur kerja pada LKS dirancang agar siswa dapat menjelaskan ciri-ciri tumbuhan paku melalui pengamatan serta 
melatih keterampilan proses siswa yang terdiri dari keterampilan mengamati, menggolongkan, menganalisis, menyimpulkan dan mengkomunikasikan. Kemu-dian untuk membantu siswa mengamati tumbuhan paku tersebut LKS ini di lengkapi dengan ilustrasi gambar bentuk-bentuk umum daun serta letak sorus pada daun. Pertanyaan-pertanyaan diskusi disu-sun untuk mengkonfirmasi hasil peng-amatan siswa dan disesuaikan dengan sasaran (siswa kelas X SMA).

\section{Validasi Lembar Kerja Siswa (LKS)}

Uji kelayakan atau validasi dilakukan oleh 2 orang dosen ahli yang terdiri dari ahli materi dan ahli bahan ajar serta 1 orang guru Biologi SMA kelas $X$. LKS divalidasi berdasarkan komponen evaluasi bahan ajar cetak meliputi aspek kelayakan isi, kelayakan kebahasaan, kelayakan penyajian dan kegrafikan.

Berdasarkan Tabel 4 hasil validasi atau kelayakan LKS, diperoleh skor rata-rata yang pada aspek kelayakan materi/isi yaitu 18 dengan persentase $90 \%$ dengan kriteria sangat baik. Kelayakan materi/isi yang dimaksutkan antara lain adalah kesesuaian materi yang disajikan dengan kurikulum yang berlaku yaitu kurikulum 2013, kesesuaian materi dengan tujuan pembelajaran, konsep dasar materi yang dikembangkan, materi yang disajikan sesuai dengan kebenaran fakta, konsep, prinsip, hukum, dan teori dibidang IPA (tidak miskonsepsi) serta kegiatan dalam LKS dapat melatih keterampilan proses peserta didik.

Kemudian pada aspek penyajian diperoleh skor rata-rata 6,7 , persentase $83 \%$ dengan kriteria sangat baik. Adapun aspek penyajian yang dimaksutkan adalah konsistensi desain dalam LKS dan penya-jian materi dapat memunculkan motivasi peserta didik. Saran yang diberikan oleh validator pada aspek ini antara lain ke-lengkapan informasi yang disajikan di sertai dengan penekanan pada konsep yang penting, sehingga revisi yang dilakukan yaitu keterangan-keterangan penting ditulis lebih tebal (Bold).

Pada Aspek bahasa, gambar dan foto diperoleh skor rata-rata yaitu 6,3 dengan persentasi $78 \%$ dan tergolong kriteria baik. Pada aspek ini komponen yang dinilai terdiri dari kesesuaian tata bahasa, ejaan dan kalimat dengan kaidah bahasa Indonesia dan kesesuaian foto dan gambar dengan materi LKS. Pada aspek ini saran yang diberikan validator antara lain adalah penggunaan kata-kata sebaiknya menggunakan kalimatkalimat efektif agar mudah dimengerti serta hubungan antar kalimat lebih jelas kemudian gambar pada lampiran LKS sebaiknya diberi keterangan. Maka dari itu revisi yang dilakukan yaitu perbaikan pada kalimatkalimat yang rancu, serta menambah keterangan pada gambara lampiran LKS.

Pada aspek Grafis diperoleh skor ratarata 14,3 dengan persentase $89 \%$ sehingga tergolong pada kriteria sangat baik. Adapun komponen aspek grafis yang dimaksutkan dalah desain cover, keserasi-an desain antara masing-masing halaman, penyajian tabel serta keter-bacaaan jenis huruf yang digunakan. perbaikan yang dilakukan pada aspek ini antara lain memandakan warna desain cover dengan warna halaman selanjutnya.

Secara keluruhan LKS ini memiliki persentase kelayakan $87 \%$ dengan kriteria sangat baik. Berdasarkan nilai persentase dari semua aspek kelayakan tersebut munjukkan bahwa LKS yang dikembang-kan telah layak dan memenuhi tiga syarat LKS yang baik menurut Widjajanti (2008) yaitu, syarat didaktik (LKS lebih menekan-kan pada proses untuk menemukan konsep), syarat konstruksi (kejelasan struktur kalimat, penggunaan bahasa, keselarasan antara tujuan pembelajaran) dan syarat teknik (tulisan, gambar dan penampilan).

Uji Keterbacaan LKS bertujuan untuk mengetahui tanggapan siswa yang dapat dijadikan tolak ukur kualitas perangkat pembelajaran yang telah dikembangkan dari aspek kepraktisan (Widoyoko, 2009). Uji 
Keterbacaan atau uji respon siswa dilakukan dikelas $X$ mipa 1 SMAN 3 kota Bengkulu dengan jumlah siswa/i sebanyak 33 orang. Berdasarkan Tabel 4.3 hasil Uji Keterbacaan diperoleh nilai rata-rata Uji Keterbacaan secara keseluruhan adalah 35,7 dengan persen-tase $89 \%$ dengan kategori sangat baik sehingga dapat dikatakan bahwa respon siswa terhadap LKS hasil pengembangan ini sangat baik atau sangat positif. Adapun tanggapan siswa yang terlihat pada saransaran yang diberikan antara lain LKS hasil pengembangan ini mampu menambah wawasan siswa tentang tumbuhan paku epifit, kemudian LKS menarik dan mudah dimengerti.

\section{PENUTUP}

\section{Simpulan}

Dari hasil identifikasi Jenis-jenis tumbuhan paku epifit pada batang kelapa sawit di kawasan perkebunan sawit gedung STQ Kelurahan sukarami kota Bengkulu diperoleh 8 jenis paku epifit yang berasal dari 1 kelas dan 4 famili berbeda yaitu Davalia trichomanoides, Davalia denticulata, Drymoglossum piloselloides, Nephrolepis biseratta, Phymatosorus scolopendria, Pyrrosia lanceolata, Asplenium nidus, Goniophlebium percussum. Desain Lembar Kerja Siswa (LKS) yang dikembangan berbasis keterampilan proses siswa dengan aspek yang dikem-bangkan meliputi aspek desain cover dan tampilan LKS, tujuan pembelajaran, ma-teri, kegiatan siswa, pertanyaan diskusi dan struktur LKS. Serta lks layak digunakan dalam pembelajaran Biologi pada materi plantae submateri tumbuhan paku (Pteridophyta) yang dibuktikan dengan hasil validasi oleh ahli materi, media dan guru Biologi.

\section{Saran}

Bagi peneliti selanjutnya, LKS hasil pengembangan ini dapat dijadikan penelitian lanjutan untuk memperbaiki pro-ses pembelajaran di kelas atau untuk meningkatlkan hasil belajar tertentu dan
Penggunaan LKS hasil penelitian identi-fikasi tumbuhan epifit ini dapat dicoba pa-da model dan metode pembelajaran lain yang berbeda pada penelitian ini.

\section{Daftar Pustaka}

Departemen Pendidikan Nasional (Depdiknas). 2008. Pedoman Memilih Menyusun Bahan Ajar dan Teks Mata Pelajaran. Jakarta: BP. Mitra Usaha Indonesia

Kementrian Pendidikan dan Kebudayaan (Kemendikbud). 2014. Konsep Dan Implementasi Kurikulum 2013. (online) (https://kemdikbud.go.id/ diakses 12 Februari 2017)

Mudjiono \& Dimyati. 2009. Belajar dan Pembelajran. Jakarta: Rineka Cipta

Permendikbud, 2016. Peraturan Menteri Pendidikan Dan Kebudayaan Nomor 22 Tahun 2016 Tentang Standar Proses Pendidikan Dasar Dan Menengah. Jakarta: Kementrian Pendidikan Dan Kebudayaan

Permendikbud, 2016. Peraturan Menteri Pendidikan Dan Kebudayaan Nomor 24 Tahun 2016 Tentang Kompentensi Inti Dan Kompetensi Dasar. Jakarta: Kementri-an Pendidikan Dan Kebudayaan

Prastowo, Andi. 2011. Panduan Kreatif membuat Bahan Ajar Inovatif. Yogyakarta: DIVA press

Sugiyono. 2010. Metode Penelitian Kuantitatif Kualitatif dan R\&D. Bandung: Alfabeta,

Widjajanti, Endah. 2008. Kualitas Lembar Kerja Siswa. Makalah ini disampaikan dalam Kegiatan Pengabdian pada Masyarakat bagi guru SMK/MAK Yogyakarta, Yogyakarta, 22 Agustus. 
Widoyoko, Eko S. 2009. Evaluasi Program

Pembelajaran. Yogyakarta: Pustaka

Pelajar. 